\title{
Nesting habitat of the Tucuman Parrot Amazona tucumana in an old-growth cloud-forest of Argentina
}

\author{
LUIS RIVERA, NATALIA POLITI and ENRIQUE H. BUCHER
}

\section{Summary}

Tucuman Parrot Amazona tucumana breeds in the cloud-forest of south-eastern Bolivia and north-western Argentina (or Southern Yungas forest). We studied the nesting requirements of the Tucuman Parrot and assessed cavity availability, reuse, and spatial pattern of nests in El Rey National Park - one of the last mature, undisturbed areas of the Southern Yungas forest. We recorded 44 nesting attempts in seven tree species, with most nests $(95 \%)$ being located in live canopy trees $>60 \mathrm{~cm}$ DBH. Most parrot nest-cavities occurred in Blepharocalix salicifolius $(60 \%)$ and cavities in this species were selected significantly more than expected based on availability. Nests were shallower and higher than nests of other Amazona species. For all years combined, mean nest density of Tucuman Parrot was $0.24 \pm 0.04$ nest ha ${ }^{-1}$ and the distance to the nearest active nest was significantly greater than the distance between all trees used as nests. Nesting pairs of Tucuman Parrot were separated by $144.1 \pm 152.8 \mathrm{~m}$, while potential nest-trees were $66.0 \pm 55.4 \mathrm{~m}$ apart. Density of suitable cavities for nesting was 4.6 cavities ha ${ }^{-1}$. Approximately 16 suitable cavities were available for each breeding pair (0.24 breeding pair ha ${ }^{-1}$ and four suitable cavities $\mathrm{ha}^{-1}$ ) and $5 \%$ of the suitable cavities available were occupied, suggesting that suitable cavities are not a limiting resource. However, due to the territorial behaviour of breeding pairs, some of these cavities are unavailable to other breeding pairs. The spatial requirements of Tucuman Parrot for nesting could limit management actions intended to increase the density of nesting pairs.

\section{Introduction}

The Tucuman Parrot Amazona tucumana is a threatened species (Birdlife International 2008), with a small geographic range restricted to the narrow strip of montane forest on the eastern slopes of the Andes from south-eastern Bolivia to north-western Argentina, an area called the Southern Yungas (Fjeldså and Krabbe 1990). The species breeds in the cloud-forest (1,400-2,200 m asl) which is dominated by Podocarpus parlatorei, Alnus acuminata, and trees of the Myrtaceae family. Among Argentina's diverse forest ecosystems, the Southern Yungas forest is particularly rich, harbouring at least 20 economically valuable tree species and 50\% of Argentina's avifauna (Brown et al. 1993, 2001). However, more than $30 \%$ of the Southern Yungas has already been transformed into agricultural land (Brown et al. 2002) and most remnant forests are highly degraded by inappropriate forest logging (Grau and Brown 200o, Pacheco and Brown 2006). In Bolivia, Southern Yungas is considered a threatened ecoregion because of forest fragmentation and conversion (Ibisch and Mérida 2003).

The significant forest reduction and degradation of the Southern Yungas have diminished the density of usable cavities which probably affects many cavity-nesting birds (Politi et al. 2010). Most psittacids are secondary cavity nesters, a group particularly sensitive to human activities, 
because they depend on other species (e.g. woodpeckers) or factors (e.g. wood decay) for the generation of cavities (Land et al. 1989) and require large old trees and snags for nesting (Mawson and Long 1994). The scarcity of suitable cavities for nesting in forest under timber exploitation led to a sharp decline of populations of Thick-billed Parrot Rhynchopsitta pachyrrhyncha in Mexico (Lanning and Shiflett 1983, Monterrubio-Rico and Enkerlin Hoefflich 2004).

Most studies have determined the requirements of parrot species for nesting: cavity entrance width, internal diameter, depth, height above ground, orientation of openings, and tree diameter at breast height (DBH), and condition (Wiens 1989, Rowley 1990, Martuscelli 1995, Renton and Salinas Melgoza 1999, Fernandes Seixas and de Miranda Mourao 2002, Vaughan et al. 2003, Monterrubio Rico and Enkerlin Hoefflich 2004, Rodriguez Castillo and Eberhard 2006). Additional requirements have been defined at stand level (e.g. stands with numerous suitable cavities) (Salinas Melgoza et al. 2009). Finally, the spacing distance between nesting pairs has been reported to influence the occupation of nest-sites (Salinas Melgoza et al. 2009). However, few studies have determined nest-site selection, i.e. characteristics of available nest-sites compared with those used (Manly et al. 2002).

Information on habitat requirements allows predictions to be made on the ability of species to adapt to disturbed habitats (Saunders et al. 1982) and to develop effective strategies for conservation and management of threatened species (Renton 2000). It is necessary to conduct studies on mature or old-growth forests (sensu Hunter and White 1997) that set a reference for future comparisons against habitat modification. Moreover, most studies on parrot species have been conducted in the tropical lowlands and very few on parrot species of the montane forests of the Andes.

Prior to this study there were no specific studies on the reproductive ecology of Tucuman Parrot there was one record of a nest, found in Chuquisaca, Bolivia, with a female incubating four eggs in January (Bond and Meyer de Schauensee 1943); a note that Tucuman Parrot nests in large trunks of Alnus or Podocarpus trees between January and March in forests located at an elevation of 2,600 m (Juniper and Parr 1998); and a comment that Tucuman Parrot places its nests at elevations between 900 and 2,100 m (Olrog pers. comm. 1986 in Low 2005). The objective of this study was to characterise the nesting habitat requirements of Tucuman Parrot in an old-growth forest and assess cavity availability, reuse, and spatial pattern of nests to set a reference for future comparisons and to discuss the conservation and management implications of our results.

\section{Methods}

\section{Study area}

We carried out the study in El Rey National Park $\left(24^{\circ} 43^{\prime} \mathrm{S}, 64^{\circ} 38^{\prime} \mathrm{W}\right)$, Salta Province, Argentina. The park is located in the central sector of the Southern Yungas forests of north-western Argentina. The central sector is located on the eastern slopes of the sub-Andean mountains (Sistema de Santa Bárbara) and is more than $100 \mathrm{~km}$ in length. El Rey National Park has an elevation range between 700 and 2,300 $\mathrm{m}$. The climate of the area is subtropical with a marked dry season (April-November) and rainy season (December-March). Rainfall ranges from 800 to $1,500 \mathrm{~mm}$ annually and mean annual temperatures are ${ }_{12-20}{ }^{\circ} \mathrm{C}$ (Mendoza 2005). El Rey National Park was created in 1948 with an area of 45, ooo ha and contains a representative sample of one of the last mature undisturbed forests of the Southern Yungas (Grau and Brown 1998).

\section{Nest search, inspection, and characteristics}

We carried out fieldwork from December to March in 2005-2009. Nest searches were conducted daily during egg-laying and incubation periods (December to mid-January) covering an area of 45 ha in the cloud-forest. We found nests by following males to the nest area and locating the cavity when the female left the nest to be fed by the male (González Elizondo 1998). Nest-cavity 
characteristics were determined by climbing (Perry 1978) and measuring cavity dimensions. We identified 44 active Tucuman Parrot nests and measured characteristics in 37 nest-cavities and nest-trees.

We recorded the following nest characteristics: 1) height from the ground to the cavity entrance; 2) size of cavity entrance (horizontal and vertical); 3) internal diameter at the cavity floor; 4) internal cavity depth from cavity entrance to the floor; 6) compass bearing of cavity entrance; 7) trunk or branch diameter at cavity entrance; 8) tree diameter at the cavity floor; 9) tree diameter at breast height (DBH); 10) tree height; II) tree species; 12) cavity origin (excavated or decayed); 13) cavity location (tree trunk, primary branch, secondary branch or third branch); 14) tree status (alive or dead); and 15) tree location (latitude and longitude).

\section{Availability of suitable cavities}

We conducted cavity sampling during the non-breeding season (April-August 2007 and 2008) when many trees are leafless. We used Distance sampling methodology to estimate the density of suitable cavities. We performed 20 variable-width, random direction, 300-m long transects that were at least $150 \mathrm{~m}$ apart. We measured the perpendicular distance from the central line of the transect to each detected cavity. We only considered a cavity to be suitable if it had a hollow chamber surrounded by sound wood (not collapsing wood), accessed by entrance holes with a floor to support an incubation chamber and a roof to provide overhead protection, a minimum diameter entrance of $5 \mathrm{~cm}$, an internal diameter of at least $15 \mathrm{~cm}$ (minimum cavity dimensions suggested for Amazona species of similar body size to Tucuman Parrot; Snyder et al. 1987, Enkerlin-Hoeflich 1995), a minimum cavity height from the ground of $2 \mathrm{~m}$, cavity depth from o to $200 \mathrm{~cm}$, and a tree $\mathrm{DBH}>30 \mathrm{~cm}$ (minimum dimensions observed for Tucuman Parrot in another stand; Rivera 2011). Therefore, the minimum characteristics used to determine a suitable cavity were in the range of the cavities used for nesting. We used a tree-peeper (Richardson et al. 1999) to estimate or measure the following cavity and tree characteristics: 1 ) height from the ground to the cavity entrance using the graduated metric scale in the telescopic rod of the tree-peeper; 2) cavity entrance diameters (horizontal and vertical); 3 ) internal diameter at the cavity floor; 4) internal cavity depth from cavity entrance to the floor. Cavity entrance bearing was measured with a compass, tree DBH was measured with metric tape, and tree height with a hypsometer. Due to treepeeper limitations we only inspected suitable cavities below 15 m (Richardson et al. 1999).

\section{Statistical analysis}

\section{Nest-cavity characteristics}

We used Manly's selection index to compare use of cavities as nest-sites in different tree species with the availability of cavities in those tree species (Krebs 1999, Manly et al. 2002). We calculated a selection coefficient and the $95 \%$ confidence interval for the categorical nest-site variable (tree species). Coefficients greater than 1.0 indicated preference, while values less than 1.O indicated avoidance (Krebs 1999, Manly et al. 2002, Aitken and Martin 2004). Selection coefficients were tested for significance using the log-likelihood ratio (G-test; Manly et al. 2002).

Frequencies of nest cavities in different categories (tree species, origin, and cavity location) were compared with a $\chi^{2}$ test. For circular data such as orientation of the nest entrance, we calculated mean \pm deviation of the angular vector $(\mu)$ together with the confidence interval of $95 \%$ using the program Oriana (Kovach 2009). A Rayleigh test was used to compare the distribution of the orientations of nest entrance with a uniform distribution. We determined the number of cavities reused by Tucuman Parrot for nesting over several breeding season. We define reuse as those cases where the same cavity was used in more than one year (Berkunsky and Reboreda 2009) and a cavity was considered to be used if it contained eggs or chicks. 


\section{Suitable cavity availability}

Cavity densities were analysed following line transect guidelines and modelled using the software Distance 5.0 (Buckland et al. 2001, Thomas et al. 2006). The model with the lowest Akaike's Information Criterion (AIC) was selected (Burnham and Anderson 2002). The adequacy of the selected model for the perpendicular distances was assessed using a Kolmogorov-Smirnov test (Buckland et al. 2001).

\section{Nest density and spatial pattern}

We determined the average nest density by calculating the mean of the number of nests found in 45 ha during the four breeding seasons. We used the Spatial Analyst tool of ArcGIS to determine distances to evaluate spacing among all simultaneously active nests and using the locations of all trees used as nest-sites over the four-year study (Salinas Melgoza et al. 2009). Each nest-tree location was considered only once for the analysis regardless of how many times the tree was reused as a nest-site. In addition, for each nest-tree used by parrots in any year we calculated the distance to the nearest neighbouring tree that had been used as a nest-site in any year. We compared the nearest neighbour distances for active nests among breeding seasons with a KruskalWallis test. To determine whether the spacing of breeding pairs differed from the distribution of all nest-trees we compared distances among active breeding pairs with distances among nest-tree for all years combined, using a Mann Whitney U-test. Using a paired Wilcoxon test, we further evaluated the influence of conspecifics on the spacing of parrot nests to compare the distance to the nearest active nest vs. the distance to the nearest potential unoccupied nest-tree for each parrot nest active in the 2008-2009 breeding season. We restricted this analysis to the 2008-2009 datasets, which had the most complete record of potential nest-trees, to avoid overduplication of distance values between years (Salinas Melgoza et al. 2009). Distance values obtained previously among all nests were used to assess the spatial pattern of nest-bearing trees and active nests (Salinas Melgoza et al. 2009) with the Average Nearest Neighbor Distance tool from ArcGIS (Ebdon 1985, Mitchell 2005). All the values are expressed as mean \pm standard deviation (SD) unless otherwise specified. We set the significance level of statistical tests at $P<0.05$.

\section{Results}

\section{Characteristics of nest-cavities and trees}

We recorded 44 Tucuman Parrot nesting attempts in 37 nest-trees, 30 during incubation and seven during brooding. Most Tucuman Parrot nests occurred in live trees (95\%) of six species, and only $5 \%$ were in nest-cavities in snags. There was a significant difference in the frequency of tree species used for nesting $\left(\chi_{3}^{2}=27.6, P<0.001\right)$, with most nest-cavities in Blephalocalyx salicifolius $(59.5 \% ; 22$ out of 37), followed by Juglans australis $(13.5 \% ; 5)$, Podocarpus parlatorei $(8.5 \% ; 3)$, Cinnamomun porphyria $(5.4 \% ; 2)$, Cedrela lilloi $(5.4 \% ; 2)$, and Myrcianthes mato $(5.4 \% ; 1)$, and $5.4 \%$ (2) of the nests were found in snags. Compared to the availability of cavities in different tree species, B. salicifolius, J. australis, and C. lilloi were used significantly more than expected $\left(G_{6}=91.6, P<0.01\right.$, Fig. 1$)$. Most nests were found in decay-originated tree cavities $(95 \% ; n=35)$, compared to nests excavated $(5 \% ; n=2)\left(\chi_{1}^{2}=21.5, P<0.001\right)$. Cavity location was predominantly in primary branches $(43 \%, n=16)$, followed by main trunk $(32 \%, n=12)$, secondary $(16 \%, n=6)$, and tertiary branches $(8 \%, n=3)\left(\chi_{3}^{2}=8.9, P<0.03\right)$.

Most nests ( $92 \%$ ) were found in trees with a DBH $>60 \mathrm{~cm}$ (Fig. 2). Average nest tree DBH was $89.9 \pm 26.9 \mathrm{~cm}$, cavities were located on average at $14.4 \pm 3.9 \mathrm{~m}$ above the ground, had a horizontal entrance diameter of $13.3 \pm 4.5 \mathrm{~cm}$, and a depth of $38.2 \pm 38.6 \mathrm{~cm}$ (Table 1 ). Orientation (bearing) of the nest entrances had a mean angular vector $(\mu)$ of $173.1 \pm 140.9^{\circ}$ $\left(95 \% \mathrm{CI}=82.2-263.9^{\circ}\right)$. The mean vector length is low, indicating there is small concentration of values near the mean $(r=0.05)$. Rayleigh test was not significant, suggesting that nest entrance 


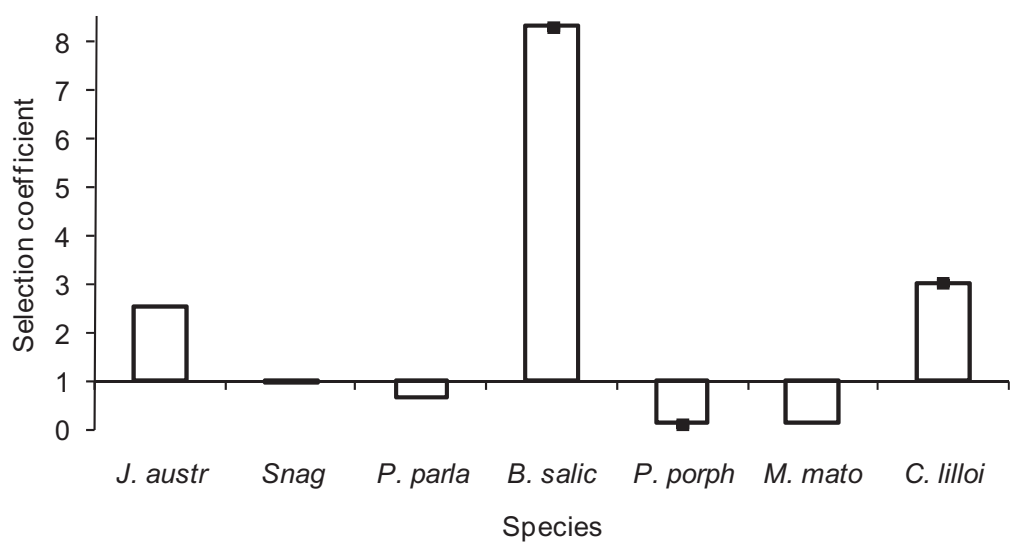

Figure 1. Selection of tree species for nesting by Tucuman Parrot in relation to availability in El Rey National Park, Salta Province, Argentina. The selection coefficient ( \pm standard error) is the proportion of trees used versus available: values $>_{1}$ implies preference; $<_{1}$ implies avoidance (Manly et al. 2002). J. austr = Juglans australis, P. parla = Podocarpus parlatorei, B. salic = Blepharocalyx salicifolius, $P$. porph $=$ Cinnamomun porphyria, $M$. mato $=$ Myrcianthes mato, C. Lilloi $=$ Cedrela lilloi. Number of nest-trees $=37$.

orientations have a uniform distribution with no evidence of a selection $(Z=0.08, P=0.98)$. Nests of Tucuman Parrot were found at an elevation range between 1,470 and $1,710 \mathrm{~m}$ asl.

Six of the 37 cavities ( $16 \%$ ) were reused. One nest-cavity was used in three breeding seasons and five were used twice. One nest-tree had two nest cavities used in separate years.

\section{Density and spatial distribution of nests}

Annual mean nest density in the study area was $0.24 \pm 0.04$ nests ha ${ }^{-1}(n=4)$. In two breeding seasons (2006-2007 and 2007-2008) the spatial pattern of active nests was dispersed $(Z=3.8$,

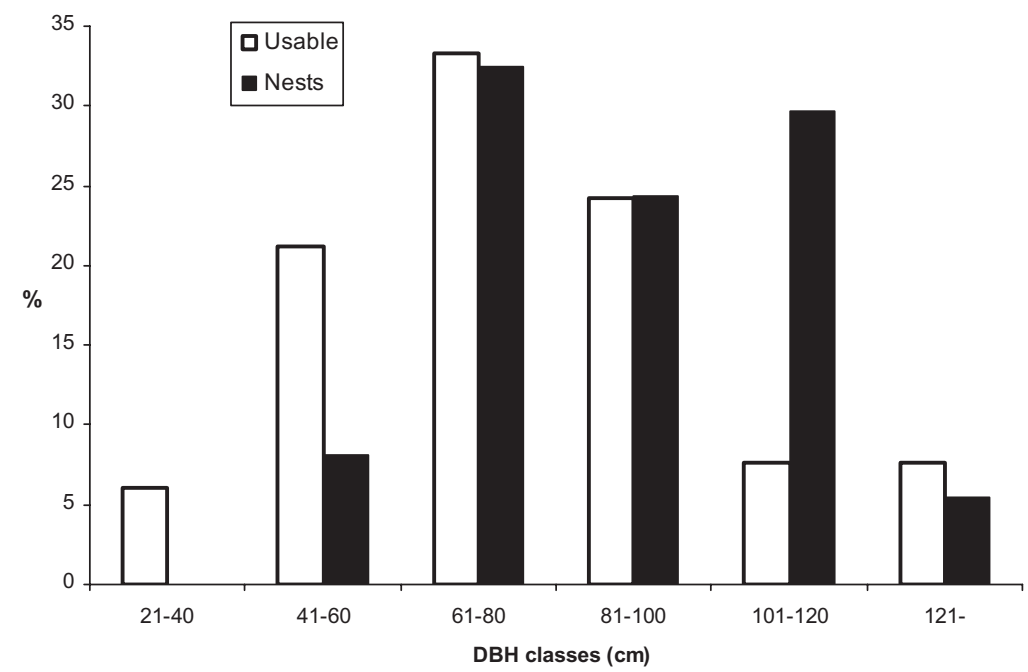

Figure 2. Percentage (\%) of nests (black bars) and usable cavities (white bars) for Tucuman Parrot according to tree DBH classes (cm) in El Rey National Park between 2005 and 2009. 
Table 1. Nest cavity and tree characteristics of Tucuman Parrot Amazona tucumana in El Rey National Park, Salta Province, Argentina. The range is shown in parentheses; SD: standard deviation, CV: coefficient of variation.

\begin{tabular}{lcr}
\hline Variable & Mean \pm SD & CV \\
\hline DBH $(\mathrm{cm})$ & $89.9 \pm 26.9(41-175)$ & 29.9 \\
Horizontal diameter $(\mathrm{cm})$ & $13.3 \pm 4.5(5-26)$ & 33.8 \\
Vertical diameter $(\mathrm{cm})$ & $23.7 \pm 13.4(7.5-67)$ & 56.6 \\
Depth $(\mathrm{cm})$ & $38.2 \pm 38.6(0-200)$ & 101.1 \\
Internal diameter $(\mathrm{cm})$ & $29.9 \pm 9.7(13-53)$ & 27.9 \\
Nest height $(\mathrm{m})$ & $14.4 \pm 3.9(8.3-23.8)$ & 27.6 \\
Tree height $(\mathrm{m})$ & $23.5 \pm 4.9(11-32)$ & 21.1 \\
Mean distance between active nests $(\mathrm{m})$ & $144.1 \pm 152.8(12-674)$ & 106.0 \\
\hline
\end{tabular}

observed distance/expected distance $=1.6$ and $Z=2.7$, observed distance/expected distance $=1.4$, respectively), random in 2005-2006 ( $Z=-0.3$, observed distance/expected distance $=0.9$ ), and intermediate between random and dispersed in 2008-2009 $(Z=1.8$, observed distance/ expected distance $=1.3$ ). The spatial pattern of all nest trees used in the four breeding season was clustered $(Z=4.2$, observed distance/expected distance $=0.6)$.

There was no significant difference in the nearest mean distance among active nests among breeding seasons $(H=1.4, P=0.69)$. For all years combined, the distance to the nearest active nest was significantly greater than the distance between all trees used as nests $(W=520, P<0.001$, Table 4). Nesting pairs of Tucuman Parrot were separated by $144.1 \pm 152.8 \mathrm{~m}$ (range $=12-674 \mathrm{~m})$, while potential nest trees were $66.0 \pm 55.4 \mathrm{~m}$ apart (range $=12-252.4 \mathrm{~m}$ ). Furthermore, for nests located in 2008-2009, the same pattern prevailed, a nesting pair being significantly farther from the nearest neighbouring pair $(138.1 \pm 165.3)$ than from the nearest available nest tree $(53.5 \pm 19.5$; $Z=2.29, P=0.02$ ).

\section{Availability of suitable cavities for nesting}

The estimation with Distance of the density of available suitable cavities for nesting was 4.6 cavities ha ${ }^{-1}\left(95 \% \mathrm{CI}=3.1-7.0\right.$ cavities $\left.\mathrm{ha}^{-1}\right)$, a coefficient of variation of $20 \%$ and an effective detection width of $9.1 \mathrm{~m}(95 \% \mathrm{CI}=7.5-11.1 \mathrm{~m})$. The selected model had a Uniform function with Cosine expansion series.

\section{Discussion}

This study characterised the nesting habitat requirements and spatial pattern of Tucuman Parrot in a reference site and thereby set a baseline against which to compare nesting habitat in sites under different management. Tucuman Parrot suffers a high predation rate of eggs and nestlings (Rivera 2011), even more than some lowland Amazona species (Enkerlin-Hoeflich 1995, Koenig 2001, Rodríguez Castillo and Eberhard 2006, Sanz and Rodríguez Ferraro 2006); therefore we expected to find higher and deeper nest cavities (Nilsson 1984, Wilcove 1985, Marsden and Jones 1997, Snyder et al. 1987, Gibbons et al. 2002). However, nest cavities of Tucuman Parrot were higher, but shallower than nests of other Amazona species from the lowlands (Tables 1 and 2). This can probably be related to a lower rate of decomposition related to specific tree and sapwood characteristics that compartmentalise decaying wood or are very resistant to fungal decay (Shigo 1984) or to a lower temperature that retards decomposition rates (Politi et al. 2010). As expected, we found that nest cavities of Tucuman Parrot have a larger internal diameter than lowland parrots nests which can be an advantage to maximise nest space and thermal insulation (Joy 2000) in a high elevation breeding habitat where low temperatures are reached. 
Table 2. Nest cavity and tree characteristics of Amazona species from the mainland and the Caribbean islands. Values are expressed as mean $\pm \mathrm{SD}$; the range is shown in parentheses.

\begin{tabular}{|c|c|c|c|c|c|c|c|c|c|c|c|}
\hline & A. autumnalis ${ }^{1}$ & A. oratrix ${ }^{1}$ & A. viridigenalis ${ }^{1}$ & A. aestiva ${ }^{2}$ & A. pretrei ${ }^{3}$ & A. brasiliensis ${ }^{4}$ & A. finschi $i^{5}$ & A. ochrocephala & A. vittata 7 & A. guildingi ${ }^{7}$ & A. ventralis ${ }^{7}$ \\
\hline DBH (cm) & $\begin{array}{l}73 \pm 30.5 \\
(40-162)\end{array}$ & $\begin{array}{c}80 \pm 45 \cdot 7 \\
(42-234)\end{array}$ & $\begin{array}{c}96 \pm 50.6 \\
(39-229)\end{array}$ & $\begin{array}{c}50.6 \pm 9.6 \\
(32-76)\end{array}$ & $\begin{array}{l}46.4 \pm 19.7 \\
(23.2-114.6)\end{array}$ & - & $\begin{array}{r}43 \pm 11.4 \\
(27 \cdot 7-66.3)\end{array}$ & - & $\begin{array}{c}95.7 \pm 30.0 \\
(59-163)\end{array}$ & $\begin{array}{c}143.2 \pm 72.7 \\
(56-372)\end{array}$ & $\begin{array}{c}80.0 \pm 20.8 \\
(46-149)\end{array}$ \\
\hline $\begin{array}{l}\text { Horizontal } \\
\quad \text { diameter }(\mathrm{cm})\end{array}$ & $\begin{array}{l}11 \pm 4 \cdot 4 \\
(7-23)\end{array}$ & $\begin{array}{c}11 \pm 3 \cdot 5 \\
(6-19)\end{array}$ & $\begin{array}{l}10 \pm 3 \cdot 7 \\
(5-23)\end{array}$ & $\begin{array}{c}7 \cdot 9 \pm 2.3 \\
(4-15)\end{array}$ & $\begin{array}{c}12.6 \pm 6.2 \\
(5-35.9)\end{array}$ & - & $\begin{array}{c}10.0 \pm 2.3 \\
(6.4-14)\end{array}$ & $\begin{array}{c}15.6 \pm 2.7 \\
(10.9-19.8)\end{array}$ & $\begin{array}{c}21.5 \pm 9.9 \\
(10-46)\end{array}$ & $\begin{array}{c}31.8 \pm 24.2 \\
\quad(8-122)\end{array}$ & $\begin{array}{l}18.0 \pm 17.4 \\
(5-99)\end{array}$ \\
\hline $\begin{array}{l}\text { Vertical } \\
\quad \text { diameter }(\mathrm{cm})\end{array}$ & $\begin{array}{l}22 \pm 12.4 \\
(9-55)\end{array}$ & $\begin{array}{c}20 \pm 12.3 \\
(10-59)\end{array}$ & $\begin{array}{l}17 \pm 11.2 \\
(8-49)\end{array}$ & $\begin{array}{c}16.2 \pm 11.3 \\
(6-79)\end{array}$ & $\begin{array}{c}48.2 \pm 51.4 \\
(8.5-278)\end{array}$ & - & $\begin{array}{c}21 \pm 16 \\
(7 \cdot 5-71.6)\end{array}$ & $\begin{array}{r}17.2 \pm 2.8 \\
(12-22.5)\end{array}$ & $\begin{array}{c}59.1 \pm 43.6 \\
(15-140)\end{array}$ & $\begin{array}{c}33.2 \pm 23.7 \\
(13-127)\end{array}$ & $\begin{array}{l}23 \cdot 7 \pm 17 \cdot 2 \\
(8-99)\end{array}$ \\
\hline Depth $(\mathrm{cm})$ & $\begin{array}{c}128 \pm 82.9 \\
(23-350)\end{array}$ & $\begin{array}{c}140 \pm 61.1 \\
(51-260)\end{array}$ & $\begin{array}{c}121 \pm 108.4 \\
(40-454)\end{array}$ & $\begin{array}{l}149 \pm 90 \\
\quad(30-450)\end{array}$ & $\begin{array}{l}84.6 \pm 71.7 \\
(6-358)\end{array}$ & $\begin{array}{c}75.2 \pm 67.4 \\
(5-420)\end{array}$ & $\begin{array}{c}66.2 \pm 51.7 \\
(24-260)\end{array}$ & $\begin{array}{r}99.2 \pm 71.2 \\
(34.8-445)\end{array}$ & $\begin{array}{c}98.0 \pm 36.9 \\
(61-170)\end{array}$ & $\begin{array}{c}140.7 \pm 136.1 \\
(36-635)\end{array}$ & $\begin{array}{c}109.0 \pm 50.1 \\
(25-290)\end{array}$ \\
\hline $\begin{array}{l}\text { Internal } \\
\quad \text { diameter }(\mathrm{cm})\end{array}$ & $\begin{array}{l}22 \pm 4.8 \\
(14-37)\end{array}$ & $\begin{array}{c}27 \pm 10.7 \\
(14-52)\end{array}$ & $\begin{array}{l}24 \pm 11.9 \\
(13-71)\end{array}$ & $\begin{array}{c}22.7 \pm 6.4 \\
\quad(14-57)\end{array}$ & $\begin{array}{l}20.7 \pm 8.7 \\
(12-70)\end{array}$ & $\begin{array}{l}25 \pm 5.8 \\
(18-40)\end{array}$ & $\begin{array}{c}19.9 \pm 6.8 \\
(10.5-35)\end{array}$ & - & $\begin{array}{c}33.0 \pm 5.6 \\
(25-41)\end{array}$ & $\begin{array}{c}39.7 \pm 14.9 \\
(25-76)\end{array}$ & $\begin{array}{c}34.0 \pm 12.8 \\
(13-71)\end{array}$ \\
\hline Nest height (m) & $\begin{array}{l}6.6 \pm 2.0 \\
(3.8-11.3)\end{array}$ & $\begin{array}{l}5.6 \pm 2.2 \\
(2.8-11.5)\end{array}$ & $\begin{array}{l}7 \cdot 3 \pm 2.4 \\
(3.8-13 \cdot .5)\end{array}$ & $\begin{array}{r}5.8 \pm 1.2 \\
(2.9-10)\end{array}$ & $\begin{array}{l}7.0 \pm 3.7 \\
(1.4-25.3)\end{array}$ & $\begin{array}{c}5 \cdot 7 \pm 2.9 \\
(1-12)\end{array}$ & $\begin{array}{l}9.7 \pm 1.7 \\
(7.4-14.7)\end{array}$ & $\begin{array}{r}12.4 \pm 2.7 \\
(9.2-16.5)\end{array}$ & $\begin{array}{c}8.0 \pm 3.2 \\
(3.2-16.8)\end{array}$ & $\begin{array}{l}17.5 \pm 5.9 \\
(6.1-30.2)\end{array}$ & $\begin{array}{r}10.3 \pm 4.9 \\
(2.1-20.7)\end{array}$ \\
\hline Tree height (m) & - & - & - & $\begin{array}{c}11.1 \pm 2.3 \\
(6-16)\end{array}$ & $\begin{array}{c}13.2 \pm 4.5 \\
(4.8-35)\end{array}$ & $\begin{array}{c}7 \cdot 3 \pm 4 \cdot 2 \\
(1-16)\end{array}$ & - & $\begin{array}{l}19.2 \pm 3.1 \\
(10.7-26.1)\end{array}$ & - & - & - \\
\hline
\end{tabular}

${ }^{1}$ Enkerlin-Hoeflich 1995; ${ }^{2}$ Berkunsky and Reboreda 2009; ${ }^{3}$ Pauletti Prestes et al. 1997; ${ }^{4}$ Martuscelli $1995{ }^{*} ;{ }^{5}$ Renton and Salinas Melgoza 1999; ${ }^{6}$ Rodríguez Castillo and Eberhard 2006; ${ }^{7}$ Snyder et al. $1987^{*}$. ${ }^{*}$ Indicates studies where means, SD, and range were not included therefore they were calculated. 
Tucuman Parrot selects three tree species for $83 \%$ of nests. Many studies have shown that Amazona species concentrate nests on $1-3$ tree species (Berkunsky and Reboreda 2009, Salinas Melgoza et al. 2009), however only a few studies compared tree species use with the availability of cavities in different tree species (Enkerlin-Hoeflich 1995, Rodríguez Castillo and Eberhard 2006). As with most Amazona (Pauletti Prestes et al. 1997, Salinas Melgoza et al. 2009, Berkunsky and Reboreda 2009), Tucuman Parrot sited a high number (95\%) of nests in living trees. However, some parrot studies showed that dead trees were used equally or more frequently than living trees; this could be related to the fact that these studies were conducted in flooded forest habitat where a high number of dead trees occurs (Martuscelli 1995, Fernandes Seixas and de Miranda Mourao 2002). Although some cavity-nesting birds show a preference in the orientation of the cavity (Snyder et al. 1987), including some parrots (Guedes 1993, Pauletti Prestes et al. 1997), we were not able to detect a particular orientation of cavity entrance used more frequently by Tucuman Parrot.

\section{Density and spatial distribution of nests}

There are very few published data on nest densities for Amazona. We reported 0.24 nests ha ${ }^{-1}$ (i.e. one nest every 4 ha) of Tucuman Parrot, a much higher value than that reported for Blue-fronted Amazon A. aestiva (0.005-0.0003 nests ha ${ }^{-1}$ depending on habitat quality; Fernandes Seixas and de Miranda Mourao 2002), but similar to the density reported for Amazona species in Mexico (0.37 nests ha ${ }^{-1}$; Enkerlin-Hoeflich 1995).

Active Tucuman Parrot nests have a dispersed distribution at a mesoscale of 45 ha of the study site. Amazona of the Caribbean islands tend to present an aggregated distribution of nests (Ridgely 1981, Snyder et al. 1987, Gnam 1990, Rojas Suarez 1991). However, these studies did not perform spatial analysis on the distribution of trees used as nests. Recently it has been suggested that behavioural spacing requirements of nesting parrots may limit breeding densities and restrict management strategies to increase numbers of nesting pairs within protected areas (Salinas Melgoza et al. 2009). A spatial pattern analysis has been carried out by Salinas Melgoza et al. (2009) who found that breeding pairs of Lilac-crowned Parrot A. finschi nest farther away than trees used as nests previously. We found a similar pattern for Tucuman Parrot since there were significantly shorter distances among nearest nest trees than distance among nearest breeding pairs in a breeding season suggesting that breeding pairs influence spacing of conspecifics.

The fact that we found a stable number of nests during the four breeding seasons for the fixed area under study, that the mean distance to the nearest breeding pairs was similar in every breeding season, and that the spatial pattern of active nests is mainly dispersed, suggests that spacing due to territorial behaviour could be limiting breeding pair density. This limitation may occur despite the availability of suitable cavities. We estimated that approximately 16 suitable cavities were available for each breeding pair ( 0.25 breeding pair ha ${ }^{-1}$ and four suitable cavities ha ${ }^{-1}$ ). The excess of available suitable cavities for each breeding pair is in agreement with the statement of Salinas Melgoza et al. (2009) that nesting pairs defend a large enough area around the nest to provide them with several cavities suitable for nesting. We did find two nests that were only $12 \mathrm{~m}$ apart, but one of them was successful and the other one failed, and although we do not have evidence of the cause of failure we cannot discount territorial behaviour and exclusion effects. The distance between nearest active nests for Tucuman Parrot ( $144 \mathrm{~m}$ ) is lower than the distance reported for Lilaccrowned Parrot (952 m) (Salinas Melgoza et al. 2009). This shorter distance could be explained by the high number of suitable cavities available in El Rey National Park old-growth forest. However, due to several biases, we cannot discount an overestimation of the availability of suitable cavities for Tucuman Parrot. First, we recorded cavities in the non-breeding season and they could have been used in the breeding season by other species. Secondly, those cavities could have been located near a predator or had a high parasite load. Thirdly, if intraspecific territoriality holds, then many of those cavities would have been inside other territories, and therefore unavailable. Additionally, our study could have also underestimated suitable cavity availability, since only cavities higher than 
$2 \mathrm{~m}$ and below $15 \mathrm{~m}$ were considered. However, since $<10 \%$ of the cavities detected were above $15 \mathrm{~m}$, this bias is probably low.

There are very few published studies on the availability of suitable cavities for Amazona. For Puerto Rican Amazon A. vittata there is a range of $0.2-0.9$ suitable cavities $\mathrm{ha}^{-1}$ depending on the definition of suitable cavity used in a range from optimum to minimal (Snyder et al. 1987). Enkerlin-Hoeflich (1995) found a density of 4.2 suitable cavities ha ${ }^{-1}$ for three Amazona species in a dry forest from México, this value being almost equal to the 4.6 suitable cavities ha $^{-1}$ we obtained for our study site.

Tucuman Parrots occupied $5 \%$ of the suitable cavities available. Similar to the values found by Enkerlin-Hoeflich (1995) in which 6\% of the cavities were used for parrots in dry forests in México, and by Brightsmith (2005) who reports an occupation of $5 \%$ of cavities in a mature tropical forest in the Peruvian Amazon. In all these forests the low percentage of occupancy could suggest that suitable cavities are plentiful (Newton 1994).

\section{Nest reuse}

A high variability (2-74\%) in the reuse of nests has been reported for 10 species of Amazona (Enkerlin-Hoeflich 1995, Renton and Salinas Melgoza 1999, Koenig 2001, Fernandes Seixas and de Miranda Mourao 2002, White et al. 2005, Rodríguez Castillo and Eberhard 2006, Berkunsky and Reboreda 2009). The percentage of reuse of cavity nests for Tucuman Parrot is similar to the value reported for Yellow-billed Amazon A. collaria inhabiting a tropical forest in Panama (Koenig 2001) and Yellow-cheeked Amazon A. autumnalis in a semi-deciduous forest in Mexico (Enkerlin-Hoeflich 1995). The relatively low percentage of reuse of nest cavities for Tucuman Parrot may show a strategy for avoiding predation, since predation is the main cause of nest loss for the species (Rivera 2011). Nests placed in new cavities have lower predation rates compared to nests in previously used cavities (Brightsmith 2005). The frequent shift of nesting sites to avoid predation is probably due to the high density of suitably cavities available for nesting in this mature forest.

\section{Conservation implications}

The probability of encountering a cavity increases with tree age (Newton 1994), therefore the surplus of suitable cavities found in this study for each breeding Tucuman Parrot pair in an oldgrowth forest is not surprising. In managed forests, the availability of suitable cavities for nesting might be lower (Newton 1994, Politi et al. 2010), and if Tucuman Parrots require a certain number of suitable cavities in their home range, it is expected that the species will be particularly vulnerable to the loss of nesting habitat through the impacts of selective logging or habitat modification (Monterrubio Rico et al. 2009). Considering that most of the Southern Yungas is under timber exploitation it is reasonable to expect that this might be the reason that Tucuman Parrot has not recovered (Rivera et al. 2010); i.e. large trees with cavities are probably lacking.

To ensure the conservation of Tucuman Parrot outside protected areas it is necessary that forest management guidelines promote the retention of large B. salicifolius trees, since this species was used more frequently than would be expected from its abundance. This might be possible because this species does not have a high timber value. However, this is probably more difficult with other tree species (such as C. lilloi and J. australis) that are selected for nesting by Tucuman Parrot but have high timber values. Finally, as suggested for Lilac-crowned Parrot (Salinas Melgoza et al. 2009), the nesting and spatial requirements of Tucuman Parrot could limit management actions intended to increase the density of nesting pairs. A mean distance among suitable cavities of at least $150 \mathrm{~m}$ could represent the minimum distance to consider in the spacing of active pairs to avoid exclusion by other pairs especially if nest box provision is necessary. 


\section{Acknowledgements}

This study was supported by Loro Parque Fundación, Conservation Leadership Programme, Rufford Small Grants, WCS Research fellowships, Scott Neotropical Fund, Overbrook Fellowships for Career development, Idea Wild, CEBio Foundation, and YPF Foundation through a Doctoral fellowship to L.R. National Park Administration granted the research permit. We are very grateful to El Rey National Park personnel for their support during fieldwork. We thank Leónidas Lizarraga for his help in GIS analysis and the field assistants and students who collaborated in the study. The manuscript was substantially improved by comments of two anonymous reviewers, J. C. Reboreda, and P. Atkinson. L. R. carried out this work as a Doctoral Student at Córdoba University in Argentina.

\section{References}

Aitken, K. E. H. and Martin, K. (2004) Nest cavity availability and selection in aspenconifer groves in a grassland landscape. Can. J. For. Res. 34: 2099-2109.

Berkunsky, I. and Reboreda, J. C. (2009) Nestsite fidelity and cavity reoccupation by Blue-fronted Parrots Amazona aestiva in the dry Chaco of Argentina. Ibis 151: 1-34.

BirdLife International (2008) Amazona tucumana. In: IUCN 2010. IUCN Red List of Threatened Species. Version 2010.3. www. iucnredlist.org

Bond, J. and Meyer de Schauensee, R. (1943) The birds of Bolivia. Part II. Proc. Ac. Nat. Sci. Philadelphia 95: 167-221.

Brightsmith, D. J. (2005) Competition, predation and nest niche shifts among tropical cavity nesters: ecological evidence. J. Avian Biol. 36: 74-83.

Brown, A. D., Placci, L. G. and Grau, H. R. (1993) Ecología y diversidad de las selvas subtropicales de la Argentina. Pp. 215-222 in F. Goin, and F. Goni, eds. Elementos de politica ambiental. Buenos Aires, Argentina: Camara de Diputados.

Brown, A. D., Grau, H. R., Malizia, L. and Grau, A. (2001) Argentina. Pp. 623-659 in M. Kappelle and A. D. Brown, eds. Bosques nublados del Neotrópico. Santo Domingo de Heredia, Costa Rica: InBio.

Brown, A. D., Grau, A., Lomáscolo, T. and Gasparri, N. I. (2002) Una estrategia de conservación para las selvas subtropicales de montaña (Yungas) de Argentina. Ecotrópico 15: 147-159.

Buckland, S. T., Anderson, D. R., Burnham, K. P., Laake, J. L., Borchers, D. L. and Thomas, L. (2001) Introduction to distance sampling; estimating abundance of biological populations. New York: Chapman and Hall.

Burnham, K. P. and Anderson, D. R. (2002) Model selection and multimodel inference: a practical information-theoretic approach. 2nd Edition. New York, USA: SpringerVerlag.

Ebdon, D. (1985) Statistics in geography. London, UK: Blackwell.

Enkerlin-Hoeflich, E. C. (1995) Comparative ecology and reproductive biology of three species of Amazon parrots in northeastern Mexico. Doctoral thesis. College Station: Texas A\&M University.

Fernandes Seixas, G. and de Miranda Mourao, G. (2002) Nesting success and hatching survival of the Blue-fronted Amazon (Amazona aestiva) in the Pantanal of Mato Grosso do Sul, Brazil. J. Field Ornithol. 73: 399-409.

Fjeldså, J. and Krabbe, N. (1990) Birds of the high Andes. Stenstrup, Denmark: Apollo Books.

Gibbons, P., Lindenmayer, D. B., Barry, S. C. and Tanton, M. T. (2002) Hollow selection by vertebrate fauna in forests of southeastern Australia and implications for forest management. Biol. Conserv. 103: 1-12.

Gnam, R. (1990) Conservation of Bahama Parrot. American Birds 44: 32-36.

González Elizondo, J. J. (1998) Productividad, causas de mortalidad en nidos y dieta de los polluelos de tres especies de loro del género Amazona en el sur de Tamaulipas. Tesis MSc. México: Universidad del NO.

Grau, H. R. and Brown, A. D. (1998) Structure, composition, and inferred dynamics of a subtropical montane forest of northwestern 
Argentina. Pp. 715-726 in F. Dallmeier and J. Camiskey, eds. Forest biodiversity in North, Central and South America, and the Caribbean. Research and monitoring. Chichester, UK: Parthenon Publishers and UNESCO.

Grau, H. R. and Brown, A. D. (2000) Development threats to biodiversity and opportunities for conservation in the mountain ranges of the Upper Bermejo River Basin, NW Argentina and SW Bolivia. Ambio 29: 445-450.

Guedes, N. M. R. (1993) Biologia Reprodutiva da Arara Azul (Anodorhonchus hyacinthinus) Pantanal-MS, Brasil. Dissertacao de Mestrado, Piracicaba: ESALQ, Univ. Sao Paulo.

Hunter, M. L. Jr. and White, A. S. (1997) Ecological thresholds and the definition of Old-Growth forest stands. Nat. Areas J. 17: 292-296.

Ibisch, P. L. and Mérida, G. (2003) Biodiversidad: La riqueza de Bolivia. Estado de conocimiento y conservación. Santa Cruz de la Sierra, Bolivia: Ministerio de Desarrollo Sostenible. Editorial FAN.

Joy, J. B. (2000) Characteristics of nest cavities and nest trees of the Red-breasted Sapsucker in coastal montane forests. J. Field Ornithol. 71: 525-530.

Juniper, P. and Parr, M. (1998) Parrots: a guide to parrots of the world. New Haven, CT: Yale University Press.

Koenig, S. E. (2001) The breeding biology of Black-billed Parrot Amazona agilis and Yellow-billed Parrot Amazona collaria in Cockpit Country, Jamaica. Bird Conserv. Internatn. 11: 205-225.

Kovach, W. L. (2009) Oriana. Circular statistics for Windows, ver. 3. Pentraeth, Wales, UK: Kovach Computing Services.

Krebs, C. J. (1999) Ecological methodology. 2nd ed. Menlo Park, CA: Benjamin Cummings.

Land, D., Marion, W. R. and O'Meara, T. (1989) Snag availability and cavity nesting birds in slash pine plantation. J. Wildl. Manage. 53: 1165-1171.

Lanning, D. V. and Shiflett, J. T. (1983) Nesting ecology of Thick-billed Parrots. Condor 85: 66-73.
Low, R. (2005) Amazon parrots, avicultura, trade, and conservation. Czech Republic: Dona/Insignis Publications.

Manly, B. F. J., Mcdonald, L. L., Thomas, D. L., Mcdonald, T. L. and Erickson, W. P. (2002) Resource selection by animals: Statistical design and analysis for field studies. Massachusetts: Kluwer Academic Publishers.

Marsden, S. and Jones, M. J. (1997) The nesting requirements of the parrots and hornbills of Sumba, Indonesia. Biol. Conserv. 82: 279-287.

Martuscelli, P. (1995) Ecology and conservation of the Red-tailed Amazon Amazona brasiliensis in southeastern Brazil. Bird Conserv. Internatn. 5: 225-240.

Mawson, P. R. and Long, J. L. (1994) Size and age parameters of nest trees used by four species of parrot and one species of cockatoo in south-west Australia. Emu. 94: 149-155.

Mendoza, E. A. (2005) El clima y la vegetación natural. Pp. 233-279 in J. L. Minetti, ed. El clima del noroeste Argentino. Tucuman, Argentina: Ed. Magna.

Mitchell, A. (2005) The ESRI Guide to GIS Analysis. Volume 2. Redlands, CA: ESRI Press.

Monterrubio-Rico, T. C. and Enkerlin Hoefflich, E. C. (2004) Present use and characteristics of Thick-billed Parrot nest sites in northwestern Mexico. J. Field Ornithol. 75: 96-103.

Monterrubio-Rico, T. C., Ortega-Rodríguez, J. M., Maríntogo, M. C., Salinas-Melgoza, A. and Renton, K. (2009) Nesting habitat of the Lilac-crowned Parrot in a modified landscape in Mexico. Biotropica 41: 361368.

Newton, I. (1994) The role of nest sites in limiting the numbers of holenesting birds: a review. Biol. Conserv. 70: 265276.

Nilsson, S. G. (1984) The evolution of nestsite selection among hole-nesting birds: the importance of nest predation and competition. Ornis Scand. 15: 167-175.

Pacheco, S. and Brown, A. D. (2006) Ecología y producción de los Cedros (género Cedrela) en las Yungas de Argentina. Tucumán, Argentina: Ediciones del Subtrópico. 
Pauletti Prestes, N. P., Martinez, J., Meyrer, P. A., Hansen, L. H. and de Negri, M. X. (1997) Nest characteristics of the Redspectacled Amazon Amazona pretrei. Ararajuba 5: 151-158.

Perry, D. R. (1978) A method of access into the crowns of emergent and canopy trees. Biotropica 10: 155-156.

Politi, N., Hunter, M. Jr. and Rivera, L. (2010) Availability of cavities for avian cavity nesters in selectively logged subtropical montane forests of the Andes. Forest Ecol. Manage. 260: 893-906.

Renton, K. (2000) Scarlet Macaw. Pp. 253257 in R. P. Reading and B. Miller, eds. Endangered animals: a reference guide to conflicting issues. Westport, CT: Greenwood Press.

Renton, K. and Salinas-Melgoza, A. (1999) Nesting behavior of the Lilac-crowned Parrot. Wilson Bull. 111: 488-493.

Richardson, D. M., Bradford, J. W., Range, P. G. and Christensen, J. (1999) A video probe system to inspect red-cockaded woodpecker cavities. Wildl. Soc. Bull. 27: 353356.

Ridgely, R. S. (1981) The current distribution and status of mainland Neotropical parrots. Pp. $233-384$ in R. F. Pasquier, ed. Conservation of New World parrots. Cambridge, UK: International Council for Bird Preservation.

Rivera, L., Rojas Llanos, R., Politi, N., Hennessey, B. and Bucher, E. H. (2010) Status of Tucumán Parrot Amazona tucumana in Bolivia: insights for a global assessment. Oryx 44: 110-113.

Rivera, L. O. (2011) Ecología, biología reproductiva y conservación del Loro alisero (Amazona tucumana) en Argentina. Tesis Doctoral. Córdoba, Argentina: Universidad Nacional de Córdoba.

Rodríguez Castillo, A. M. and Eberhard, J. R. (2006) Reproductive behavior of the Yellow-crowned Parrot (Amazona ochrocephala) in Western Panama. Wilson J. Orn. 118: 225-236.

Rojas Suarez, F. (1991) Biología reproductiva de la cotorra Amazona barbadensis en la Peninsula de Macanao. Senior Thesis. Caracas, Venezuela: Univ. Central de Venezuela.
Rowley, I. (1990) Behavioural ecology of the Galah Eolophus roseicapillus in the wheatbelt of Western Austalia. Sydney, Australia: Surrey Beatty.

Salinas-Melgoza, A., Salinas-Melgoza, V. and Renton, K. (2009) Factors influencing nest spacing of a secondary cavity-nesting parrot: habitat heterogeneity and proximity of conspecifics. Condor 111: 305-313.

Sanz, V. and Rodriguez-Ferraro, A. (2006) Reproductive parameters and productivity of the Yellow-shouldered Parrot on Margarita island, Venezuela: a long-term study. Condor 108: 178-192.

Saunders, D. A., Smith, G. and Rowley, I. (1982) The availability and dimensions of tree hollows that provide nest sites for cockatoos in Western Australia. Austral. Wild. Res. 9: 541-556.

Shigo, A. L. (1984) Compartmentalization: a conceptual framework for understanding how trees grow and defend themselves. Annu. Rev. Phytopathol. 22: 189-214.

Snyder, N. F. R., Wiley, J. W. and Kepler, C. B. (1987) The parrots of Luquillo: natural history and conservation of the Puerto Rican Parrot. Los Angeles, CA: Western Foundation of Vertebrate Zoology.

Thomas, L., Laake, J. L., Strindberg, S., Marques, F. F. C., Buckland, S. T., Borchers, D. L., Anderson, D. R., Burnham, K. P., Hedley, S. L., Pollard, J. H., Bishop, J. R. B. and Marques, T. A. (2006) Distance 5.o Release 2. University of St. Andrews, UK: Research Unit for Wildlife Population Assessment. [http://www.ruwpa.st-and.ac. $\mathrm{uk} /$ distance/].

Vaughan, C., Nemeth, N. and Marineros, L. (2003) Ecology and management of natural and artificial Scarlet Macaw (Ara macao) nest cavities in Costa Rica. Ornitol. Neotrop. 14: 381-396.

White, T. H. Jr, Abreu-González, W., ToledoGonzález, M. and Torres-Báez, P. (2005) Artificial nest cavities for Amazona Parrots. Wildl. Soc. Bull. 33: 756-76o.

Wiens, J. A. (1989) The ecology of bird communities. Cambridge, UK: Cambridge University Press.

Wilcove, D. S. (1985) Nest predation in forest tracts and the decline of migratory songbirds. Ecology 66: 1211-1214. 
LUIS RIVERA*

Facultad de Ciencias Agrarias, UNJu, Fundación CEBio, Roca 44 S.S. de Jujuy (46oo), Jujuy, Argentina.

NATALIA POLITI

Facultad de Ciencias Agrarias, UNJu, CONICET, Alberdi 47 S.S. de Jujuy (460o), Jujuy, Argentina.

ENRIQUE H. BUCHER

Centro de Zoología Aplicada, UNC, CONICET, C.C. 122, Córdoba (50oo), Argentina.

*Author for correspondence; email: luosvriv@yahoo.com

Received 4 September 2010; revision accepted 20 March 2011; Published online 4 January 2012 